\title{
Effects of overconditioning on pancreatic insulin secretory capacity, fat infiltration, and the number and size of islets in dairy cows at the end of the dry period
}

\author{
H. Bogaert, ${ }^{*}$ J. De Koster, ${ }^{*}$ W. Van den Broeck, $†$ M. Van Eetvelde, ${ }^{*}$ and G. Opsomer*1 \\ *Department of Reproduction, Obstetrics and Herd Health, Faculty of Veterinary Medicine, and \\ †Department of Morphology, Faculty of Veterinary Medicine, Ghent University, Salisburylaan 133, 9820 Merelbeke, Belgium
}

\begin{abstract}
In the present study, we tested the hypothesis that overconditioning in dairy cows at the end of the dry period leads to infiltration of fat and alterations of the insulin secretory capacity of the pancreas. Pregnant Holstein Friesian dairy cows were selected based on body condition score (BCS) at the start of the dry period. Body condition score varied between cows to have optimal conditioned $(2.5<\mathrm{BCS} \leq 3.5, \mathrm{n}=5)$ and overconditioned $(3.5<\mathrm{BCS} \leq 5, \mathrm{n}=5)$ cows. All animals underwent an intravenous glucose tolerance test (IVGTT) at an average of $260 \mathrm{~d}$ of gestation to measure the pancreatic insulin secretory capacity and assess peripheral insulin sensitivity regarding glucose metabolism. Eight days after the IVGTT, animals were slaughtered. The pancreas was dissected and weighed and tissue samples were taken for histological analysis. Results revealed that overconditioning in dairy cows led to fat infiltration in the pancreas and an increase in size of pancreatic islets expressed relative to the total area of pancreatic tissue. In addition, results revealed a positive correlation between serum fatty acid concentration and peak insulin concentration and area and number of pancreatic islets expressed relative to the total area of pancreatic tissue. The IVGTT revealed that overconditioned animals have a higher insulin secretory capacity of the pancreas, as demonstrated by higher peak insulin concentration, higher acute insulin response to glucose, and higher area under the curve (AUC) for insulin compared with optimal conditioned cows. A higher AUC for glucose during the first 60 min following administration of the glucose bolus in overconditioned cows indicates an insulin-resistant state regarding glucose metabolism. Our results suggest that the pancreas of overconditioned dairy cows at the end of gestation compensates for the concomitantly
\end{abstract}

Received April 17, 2018.

Accepted August 23, 2018.

${ }^{1}$ Corresponding author: Geert.Opsomer@Ugent.be elevated level of peripheral insulin resistance by greater secretion of insulin.

Key words: dairy cow, overconditioning, endocrine pancreas, insulin

\section{INTRODUCTION}

In humans, obesity is characterized by peripheral insulin resistance (Weyer et al., 1999; Kahn et al., 2006). Concomitant alterations in the functioning of pancreatic $\beta$-cells can have major detrimental metabolic consequences (Saltiel and Kahn, 2001; Cerf, 2013). Increased serum fatty acids (FA) and increased plasma glucose hinder the insulin secretory capacity of the pancreas, which may lead to the development of type 2 diabetes mellitus (Weyer et al., 1999; Kahn, 2003; DeFronzo, 2004).

In dairy cows, overconditioning is associated with the occurrence of a combination of metabolic, digestive, infectious, and reproductive conditions, which is known as the "fat cow syndrome" (Morrow, 1976; Roche et al., 2013). Excessive accumulation of body fat in dairy cows at the end of the dry period is associated with insulin resistance (De Koster et al., 2015). Jaakson et al. (2018) demonstrated that insulin resistance in adipose tissue prepartum is related to reduced glucose transporter type 4 (GLUT4) protein synthesis in obese cows. In dairy cows, it is not known whether the pancreas compensates for this insulin resistance by increased insulin secretion. Typically, initiation of lactation in dairy cows is characterized by a sharp decrease in insulin secretion, resulting in lower peripheral insulin concentrations (Bell and Bauman, 1997). In the periparturient period, high BHB and FA concentrations have been associated with lower insulin secretion by the pancreas (Bossaert et al., 2008; Kerestes et al., 2009). Cows suffering from cystic ovarian follicles were found to have lower peripheral insulin concentrations during the first weeks after calving (Vanholder et al., 2005) and lower insulin secretion following an intravenous glucose bolus (Opsomer et al., 1999). 
In the present study, we hypothesized that overconditioning in dairy cows at the end of the dry period leads to infiltration of fat and alterations of the insulin secretory capacity of the pancreas. To test this hypothesis, the aims of the present study were to determine the effect of overconditioning at the end of the dry period (1) on insulin secretion during an intravenous glucose tolerance test (IVGTT), (2) on the number and size of pancreatic islets, and (3) on the amount of fat infiltration in the pancreas. A further objective was to determine associations between functional and histological characteristics of the endocrine pancreas.

\section{MATERIALS AND METHODS}

All experimental procedures were approved by the ethical committee of the Faculty of Veterinary Medicine, Ghent University, Belgium (EC2010/149).

\section{Study Design}

A detailed description of the experimental design can be found in De Koster et al. (2015). Briefly, 10 clinically healthy Holstein Friesian cows at the end of gestation were selected based on BCS at the start of the dry period (approximately $7 \mathrm{wk}$ before the expected parturition date). Animals were selected to ensure a range in BCS from optimal conditioned $(2.5<\mathrm{BCS}$ $\leq 3.5)$ to overconditioned $(3.5<\mathrm{BCS}<5)$. Animals were fed according to the NRC (2001) requirements for cows at the end of pregnancy. At the farm, cows were given the lactation ration diluted with chopped straw (67:33 ratio on a DM basis); at the faculty, cows were offered $6 \mathrm{~kg}$ (DM) of corn silage and grass hay daily for ad libitum intake (De Koster et al., 2015). Starting 2 mo before expected parturition date, animals were monitored weekly for BCS (Edmonson et al., 1989) and backfat thickness (BFT; Schröder and Staufenbiel, 2006).

\section{Intravenous Glucose Tolerance Test}

At an average gestation of $260 \mathrm{~d}$ (range 258 to $262 \mathrm{~d}$ ), IVGTT were performed as described by De Koster et al. (2016). A glucose bolus (250 mg/kg of BW, Glucose Dextrose $300 \mathrm{~g} / \mathrm{L}$, Eurovet, Heusden-Zolder, Belgium) was administered through a catheter (16-gauge, Cavafix Certo338, B. Braun, Instrulife, Oostkamp, Belgium) fitted into the left jugular vein. Blood samples for the determination of glucose and insulin concentrations were obtained from a catheter fitted into the right jugular vein at 15 and 5 min before the start of the glucose infusion and at $0,5,10,15,20,30,40,50$,
$60,75,90,120,150$, and $180 \mathrm{~min}$ after the end of the glucose infusion.

\section{Blood Analyses and Calculations}

Blood samples for glucose determination were taken in fluorinized blood tubes (Terumo Europe NV, Leuven, Belgium). Samples for insulin and FA determination were taken in gel-coated blood tubes (Terumo Europe NV). Blood samples were centrifuged for 20 min $(2,460$ $\times \mathrm{g}, 7^{\circ} \mathrm{C}$ ) within $2 \mathrm{~h}$ after collection. Serum and plasma samples were stored at $-80^{\circ} \mathrm{C}$ until analysis. Serum FA concentrations were determined by a commercial laboratory (Mediclab, Aalst, Belgium) using an enzymatic endpoint method. Intra- and inter-assay coefficients of variation $(\mathbf{C V})$ were 1.03 and $1.11 \%$, respectively. Serum insulin concentrations were determined using a bovine-specific insulin ELISA (Mercodia, Uppsala, Sweden). Intra- and interassay CV were 4.74 and $9.57 \%$, respectively. Glucose concentrations were determined by a commercial laboratory (Mediclab) using the hexokinase method (GLUC3 Cobas, Roche Diagnostics GmbH, Mannheim, Germany). Intra- and interassay CV were 0.82 and $1.18 \%$, respectively.

Serum FA concentrations were determined as the average FA concentration in the 2 blood samples taken in the 2 wk preceding the IVGTT and were used to evaluate the effects of chronic exposure to elevated FA on the pancreas. Basal glucose and insulin values were calculated as the average concentrations measured at 15 and 5 min before glucose infusion. Based on measured blood insulin concentrations at the different time points, the areas under the curve for glucose $\left(\mathbf{A} \mathbf{U C}_{\text {glu }}\right)$ and insulin $\left(\mathbf{A} \mathbf{U} \mathbf{C}_{\text {ins }}\right)$ were calculated as the incremental area using the trapezoidal rule (Cardoso et al., 2011). Peak concentrations of insulin $\left(\mathbf{P}_{\text {ins }}\right)$ and glucose $\left(\mathbf{P}_{\text {glu }}\right)$ were calculated as the maximum concentration of insulin and glucose during the IVGTT corrected for basal levels. The acute insulin response to glucose (AIRg) and the insulin sensitivity index (Si) were calculated using MINMOD software (Boston et al., 2003). The elimination rate of insulin (\%/min) was computed using the equations described by Pires et al. (2007).

\section{Sampling and Histology of the Pancreas}

Animals were slaughtered at an average gestation of $267 \mathrm{~d}$ (range: 266 to $269 \mathrm{~d}$ ) as described in detail by De Koster et al. (2015). Immediately after slaughter, the pancreas was dissected and weighed. Fifteen samples of the pancreas were taken using the systematic random sampling (SRS) procedure (Howard and Reed, 2004) and fixed in phosphate-buffered formaldehyde (3.8\%) 
for $24 \mathrm{~h}$. After fixation, tissue samples were processed with an STP 420D Tissue Processor (Microm; Prosan, Merelbeke, Belgium) and embedded (embedding center EC 350-1, Microm, Prosan). Specimens were sectioned (8 $\mu \mathrm{m}$ thick) with a rotary microtome HM 360 (Microm, Prosan). Sections, one per specimen, were stained with hematoxylin and eosin using Sakura Lineair Stainer II (Sakura, Berchem, Belgium) and mounted with a xylene-based mounting solution (DPX Mountant for Microscopy, VWR International, Oud-Heverlee, Belgium). On each section, 5 micrographs (magnification of 100×; Supplemental Figure S1; https://doi.org/10 .3168/jds.2018-14931) were taken at random using a digital camera (Olympus DP50, Olympus NV, Aartselaar, Belgium) installed on a microscope (Olympus BX61) and analyzed using the image analysis software Cell^F (Olympus NV). The total area of pancreatic tissue $\left(\mu \mathrm{m}^{2}\right)$, the area of fat within the pancreas $\left(\mu \mathrm{m}^{2}\right)$, the area of each pancreatic islet $\left(\mu \mathrm{m}^{2}\right)$, and the number of pancreatic islets were determined. The area of fat, area of pancreatic islets, and number of pancreatic islets were expressed relative to the total area of pancreatic tissue.

\section{Statistical Analyses}

All statistical analyses were performed using SAS software (version 9.4; SAS Institute Inc., Cary, NC). To check whether BCS and BFT changed during the dry period, BCS and BFT were modeled (PROC MIXED) with cow as the random factor and time points during the dry period as repeated measurements within cow. Subsequently, animals were divided in 2 groups based on BCS (calculated as the average BCS during the complete dry period): optimal conditioned animals $(2.5<\mathrm{BCS} \leq 3.5, \mathrm{n}=5)$ and overconditioned animals $(3.5<\mathrm{BCS} \leq 5, \mathrm{n}=5)$. Descriptive statistics (PROC MEANS) are expressed as mean \pm standard error of the means (SEM) unless otherwise indicated. Normality of the variables (PROC UNIVARIATE) was checked using the Kolmogorov-Smirnov test $(\mathrm{P}<0.01)$. To assess differences between the optimal and overconditioned animals, the PROC ANOVA function for normally distributed variables and the PROC NPAR1WAY/ Wilcoxon function for non-normally distributed variables (area of fat, $\mathrm{Si}$, and basal insulin) were used. Heterogenity of variances was checked using the Levene test (PROC GLM). Spearman rank correlation coefficients $\left(\mathbf{r}_{\mathrm{s}}\right)$ were calculated to determine the correlation between variables representing pancreatic histological and functional characteristics using the PROC CORR function. Significance and tendency were declared at $\mathrm{P}$ $<0.05$ and $0.05<\mathrm{P}<0.1$, respectively.
Table 1. Body condition score, backfat thickness (BFT), and serum fatty acid (FA) concentration (means \pm SEM) during the dry period in optimal-conditioned $(2.5<\mathrm{BCS} \leq 3.5 ; \mathrm{n}=5)$ and overconditioned $(3.5<\mathrm{BCS} \leq 5 ; \mathrm{n}=5)$ dairy cows at the end of pregnancy (data from De Koster et. al., 2015)

\begin{tabular}{lccc}
\hline Variable & $\begin{array}{c}\text { Optimal } \\
\text { conditioned }\end{array}$ & Overconditioned & P-value \\
\hline $\mathrm{BCS}^{1}$ & $3.17 \pm 0.10$ & $4.35 \pm 0.21$ & $<0.05$ \\
$\mathrm{BFT}^{2}(\mathrm{~cm})$ & $1.29 \pm 0.20$ & $3.14 \pm 0.43$ & $<0.01$ \\
$\mathrm{FA}^{3}(\mathrm{mmol} / \mathrm{L})$ & $0.16 \pm 0.04$ & $0.38 \pm 0.07$ & $<0.05$ \\
\hline
\end{tabular}

${ }^{1}$ Calculated as the average BCS during the dry period.

${ }^{2}$ Calculated as the average BFT during the dry period.

${ }^{3}$ Serum fatty acid concentrations were calculated as the average of the 2 blood samples taken in the $2 \mathrm{wk}$ preceding the intravenous glucose tolerance test (IVGTT).

\section{RESULTS}

\section{Animal Characteristics and Serum Fatty Acids}

The BW of the overconditioned cows was numerically higher $(751 \pm 36 \mathrm{~kg})$ than that of optimal conditioned cows $(684 \pm 27 \mathrm{~kg} ; \mathrm{P}=0.18)$. Body condition score did not change within individual cows during the dry period. The BCS and BFT of optimal conditioned cows were lower than that of overconditioned cows (Table 1). Body condition score and BFT were highly correlated $(\mathrm{r}=0.95 ; \mathrm{P}<0.05)$. Serum FA concentrations were higher in overconditioned cows than in optimal conditioned cows (Table 1) and were positively correlated with BCS and BFT $(\mathrm{r}=0.67$ and 0.73 for BCS and $\mathrm{BFT}$, respectively, and $\mathrm{P}<0.05$ for both).

\section{Histological Pancreatic Characteristics}

Absolute and relative pancreatic weights did not differ between optimal and overconditioned cows (Table 2 ). Comparisons of the area of pancreatic islets and the area of fat between optimal and overconditioned cows are given in Table 2. The areas of pancreatic islets and fat increased in overconditioned cows. The number of pancreatic islets did not differ significantly between the 2 groups of animals. The area and number of pancreatic islets were positively correlated with serum FA concentrations (Table 3).

\section{Insulin Secretory Capacity of the Pancreas and Elimination Rate of Insulin}

Comparisons of the insulin profiles between optimal and overconditioned cows are given in Table 4 and Figure 1. The $\mathrm{P}_{\text {ins }}$ tended to differ between the optimal and overconditioned animals and was positively correlated with serum FA concentration $\left(\mathrm{r}_{\mathrm{s}}=0.61 ; \mathrm{P}=0.06\right)$. 
Table 2. Weight and histological characteristics (means \pm SEM) of the pancreas in optimal-conditioned $(2.5<\mathrm{BCS} \leq 3.5 ; \mathrm{n}=5)$ and overconditioned $(3.5<\mathrm{BCS} \leq 5 ; \mathrm{n}=5)$ dairy cows at the end of pregnancy

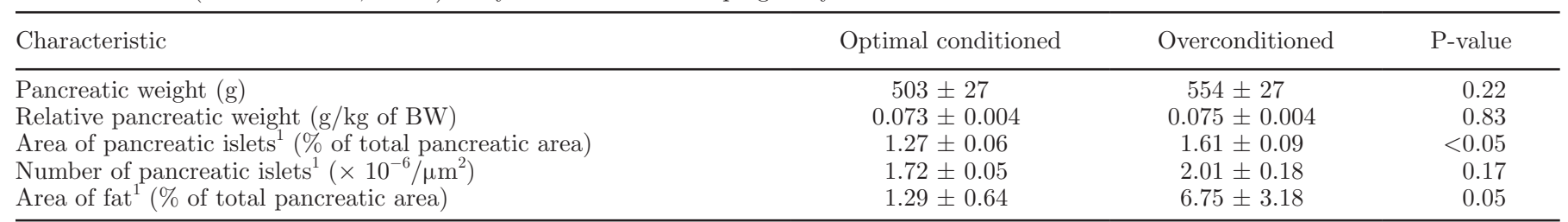

${ }^{1}$ Area of pancreatic islets, number of pancreatic islets, and area of fat were expressed relative to the total area of pancreatic tissue determined using the imaging system Cell^F (Olympus NV, Aartselaar, Belgium).

The $\mathrm{P}_{\text {ins }}$ was not correlated with the area and number of pancreactic islets nor with area of fat. The $\mathrm{AUC}_{\text {ins }}$ from 0 to $30 \mathrm{~min}, 0$ to $60 \mathrm{~min}, 0$ to $120 \mathrm{~min}$, and 0 to 180 min tended to be higher $(0.05<\mathrm{P}<0.1)$ in the group of overconditioned animals. The $\mathrm{AUC}_{\text {ins }}$ for the different time intervals ( 0 to 60,120 , or $180 \mathrm{~min}$ ) and basal insulin concentrations were positively correlated with the area of fat in the pancreas (Table 3 ). The AU$\mathrm{C}_{\text {ins }}$ for the interval of 0 to $30 \mathrm{~min}$ and the AIRg were not correlated with the area and number of pancreactic islets and the area of fat. The elimination rate of insulin did not differ between optimal and overconditioned cows (Table 4).

\section{Insulin Sensitivity Parameters}

Comparison of the insulin sensitivity parameters between optimal and overconditioned cows are given in Table 5 . The Si (as determined by MINMOD software) did not differ between optimal and overconditioned cows. The $\mathrm{AUC}_{\text {glu }}$ tended to be higher $(0.05<\mathrm{P}<0.1)$ in the group of overconditioned animals for the time interval from 0 to $60 \mathrm{~min}$.

\section{DISCUSSION}

Dairy cows with a BCS $>3.5$ near calving are at a higher risk of a variety of diseases in the immediate postpartum period. Overfeeding dairy cows during the dry period leads to elevated basal prepartum insulin concentrations, whereas underfeeding decreases the circulating insulin levels (Holtenius et al., 2003; Schoenberg et al., 2012). Similarly, insulin secretion during an IVGTT is up- or downregulated due to over- or underfeeding, respectively (Holtenius et al., 2003; Schoenberg et al., 2012). To avoid the effect of over- and underfeeding on the insulin secretory capacity of the pancreas, cows in the present study were fed according to their requirements.

In the present study, we observed an appreciable lipid infiltration in the pancreas of overconditioned cows. Furthermore, overconditioning was associated with a relative increase in the amount of endocrine tissue represented by the area of pancreatic islets. It should be mentioned that we examined the pancreatic endocrine tissue at the level of the pancreatic islets using hematoxylin and eosin staining, not at the cellular level.

Table 3. Spearman rank correlation coefficients between the histological and functional pancreatic characteristics $(\mathrm{n}=10)$

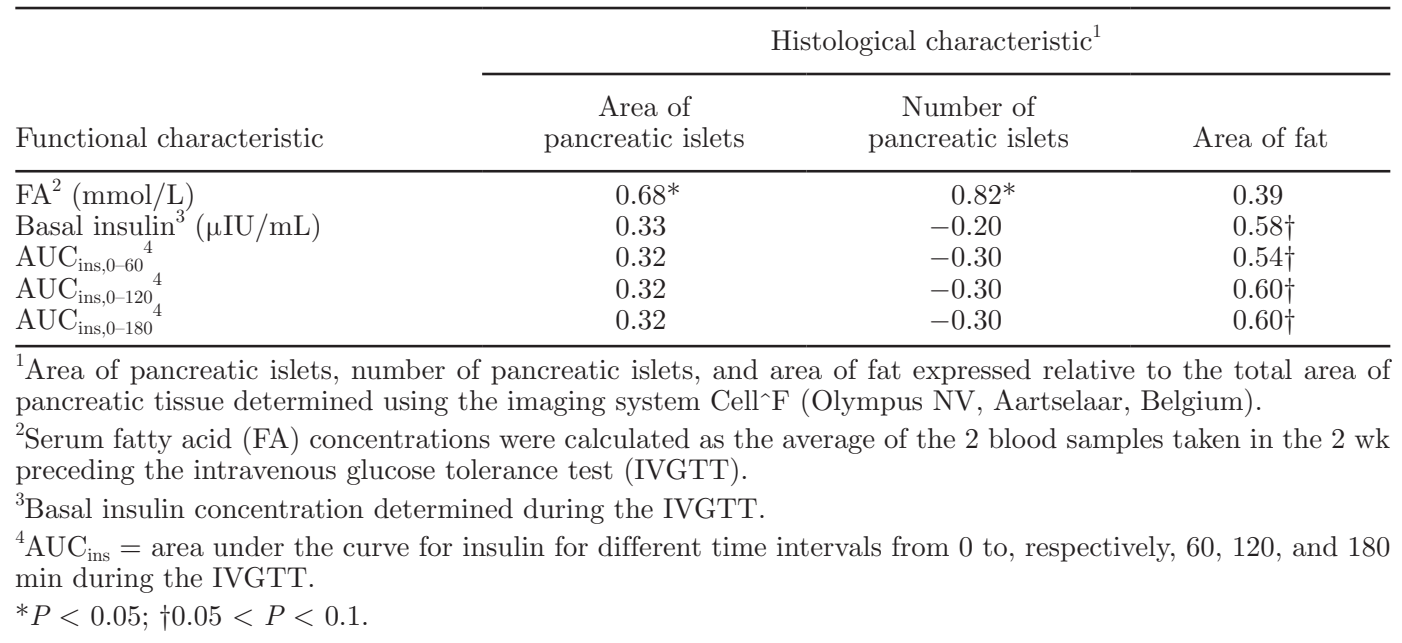


Table 4. Insulin secretory capacity of the pancreas and elimination rate of insulin (means \pm SEM) determined during intravenous glucose tolerance tests (IVGTT) in optimal-conditioned $(2.5<\mathrm{BCS} \leq 3.5 ; \mathrm{n}=5)$ and overconditioned $(3.5<\mathrm{BCS} \leq 5 ; \mathrm{n}=5)$ dairy cows at the end of pregnancy

\begin{tabular}{lccc}
\hline Variable & Optimal conditioned & Overconditioned & P-value \\
\hline Basal insulin $(\mu \mathrm{IU} / \mathrm{mL})$ & $6.53 \pm 1.00$ & $12.52 \pm 4.26$ & 0.21 \\
$\mathrm{P}_{\text {ins }}{ }^{1}(\mu \mathrm{IU} / \mathrm{mL})$ & $92.2 \pm 14.9$ & $175.2 \pm 41.8$ & 0.10 \\
$\mathrm{AIR}_{\mathrm{g}}{ }^{2}{ }{ }_{3}$ & $1,505 \pm 267$ & $2,799 \pm 593$ & 0.08 \\
$\mathrm{AUC}_{\text {ins }, 0-30}{ }_{3}$ & $2,224 \pm 413$ & $4,189 \pm 860$ & 0.07 \\
$\mathrm{AUC}_{\text {ins }, 0-60}{ }_{3}$ & $3,636 \pm 668$ & $6,974 \pm 1,546$ & 0.08 \\
$\mathrm{AUC}_{\text {ins }, 0-120}{ }_{3}$ & $4,788 \pm 841$ & $9,755 \pm 2,269$ & 0.07 \\
$\mathrm{AUC}_{\text {ins }, 0-180}$ & $4,926 \pm 879$ & $10,257 \pm 2,351$ & 0.07 \\
$\mathrm{ER}_{\text {ins }}^{4}(\% / \mathrm{min})$ & $1.62 \pm 0.17$ & $1.67 \pm 0.09$ & 0.79 \\
\hline
\end{tabular}

${ }^{1} \mathrm{P}_{\text {ins }}=$ peak insulin concentration.

${ }^{2} \mathrm{AIR}_{\mathrm{g}}=$ acute insulin response to glucose (derived from the minimal model).

${ }^{3} \mathrm{AUC}_{\text {ins }}=$ area under curve for insulin for different time intervals from 0 to, respectively, $30,60,120$, and 180 min during the IVGTT.

${ }^{4} \mathrm{ER}_{\text {ins }}=$ elimination rate of insulin during the IVGTT.

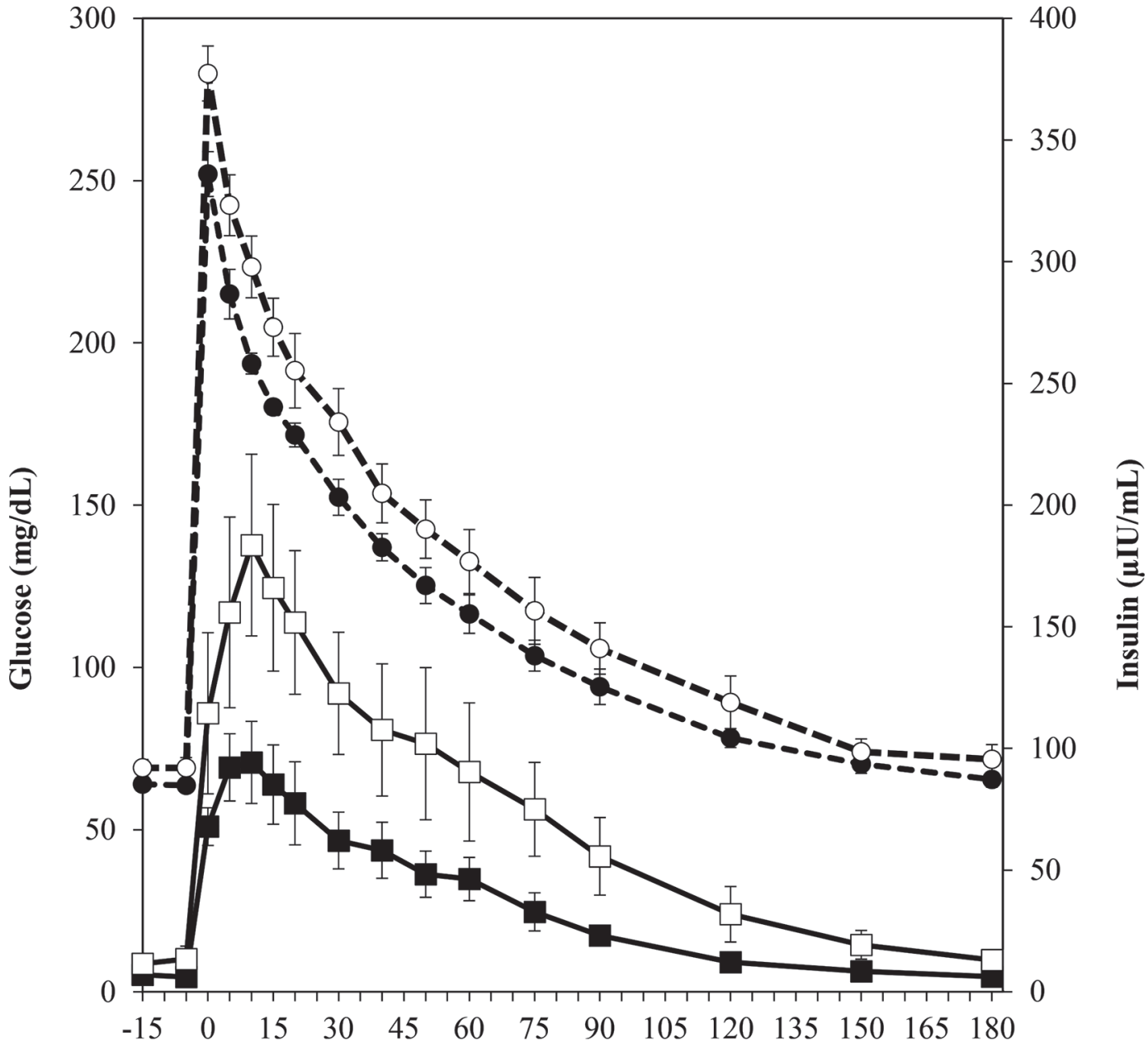

Time (min)

Figure 1. Results of the intravenous glucose tolerance test. Mean \pm SEM of the serum insulin ( $\mu \mathrm{IU} / \mathrm{mL}$; right-hand axis) of the optimalconditioned $(2.5<\mathrm{BCS} \leq 3.5 ; \mathrm{n}=5 ; \mathbf{\square}$; solid line) and overconditioned ( $3.5<\mathrm{BCS} \leq 5 ; \mathrm{n}=5 ; \square$; solid line) cows and glucose (mg/dL; left-hand axis) concentrations of the optimal-conditioned $(2.5<\mathrm{BCS}<3.5 ; \mathrm{n}=5$; $\bullet$; dotted line) and overconditioned $(3.5<\mathrm{BCS}<5 ; \mathrm{n}=5 ; \bigcirc$; dotted line) cows. A glucose bolus (250 mg per $\mathrm{kg}$ of BW) was administered at time 0 min and blood samples were taken at time $-15,-5,0,5,10,15$, 20, 30, 40, 50, 60, 75, 90, 120, 150, and $180 \mathrm{~min}$ (data from De Koster et al., 2016). 
Pancreatic islets are composed of clusters of different hormone-producing cells, such as insulin-producing $\beta$-cells and glucagon-producing $\alpha$-cells (Hayirli, 2006; Steiner et al., 2010). Examination of the pancreas at the level of the pancreatic islets and not at the cellular level implies that there may have been undetected changes in cell composition within the islets (Cnop et al., 2007; Rorsman and Braun, 2013). Cerf (2013) described the critical role of maintaining adequate $\beta$-cell mass in response to various fluctuations in glucose demands. This maintenance of $\beta$-cell mass was achieved by the balance of an increase in $\beta$-cell number and size by proliferation, neogenesis, hyperplasia, and hypertrophy with a decrease in $\beta$-cell number and size by cell death, hypotrophy, and hypoplasia, respectively (Cerf, 2013). Further research at the cellular level, and specifically at the level of the insulin-producing $\beta$-cells, is needed to confirm our findings. Our results suggest that the area of pancreatic islets might reflect short-term adaptation of the pancreas to an increase of FA in overconditioned cows at the end of pregnancy. Pancreatic area of fat, as assessed in the present study, might reflect long-term effects of positive energy balance at the end of lactation when excessive energy is deposited in adipose stores throughout the body.

To assess the insulin secretory capacity of pancreatic $\beta$-cells, insulin concentrations measured during an IVGTT are used as functional parameters (Pacini and Bergman, 1986). The AIRg and Si represent $\beta$-cell function in relation to peripheral insulin sensitivity and, when used in combination, are regarded as an overall measure of the ability of the pancreatic $\beta$-cells to release insulin normalized to the degree of insulin resistance (Boston et al., 2003). The combination of the dynamic relation between insulin secretion and elimination results in the typical profile of serum insulin concentrations during an IVGTT (De Koster and Opsomer, 2013). Overconditioned cows in our study had a higher insulin secretory capacity, and insulin concentra- tions remained at a higher level during the IVGTT. The elevated levels of insulin in overconditioned cows may be caused by an increase in insulin secretion, a slower elimination of insulin, or a combination of both (Bossaert et al., 2008). The blood insulin concentration at the beginning of the IVGTT is mainly influenced by insulin secretion due to the administered glucose bolus. Insulin concentrations at the end of the IVGTT are, in contrast, mainly determined by the elimination of insulin. Elimination of insulin from the peripheral circulation occurs by binding and internalization via insulin receptors of the peripheral tissues and by metabolization in the liver (Reynolds et al., 2003; De Koster and Opsomer, 2013). In the current study, elimination rates of insulin did not differ between optimal and overconditioned cows. The different insulin profile following the glucose bolus between optimal and overconditioned cows was most probably due to increased insulin secretion in overconditioned cows. Insulin resistance is defined as a state where a normal concentration of insulin induces a decreased biological response in the insulinsensitive tissues (Kahn, 1978; De Koster and Opsomer, 2013). Peak glucose was higher and the glucose AUC in the first $60 \mathrm{~min}$ tended to be higher in overconditioned cows in the present study, which is, according to Cerf (2013) and De Koster et al. (2016), suggestive of an insulin-resistant state. The results of the present study suggest that in pregnant overconditioned cows at the end of the dry period, the endocrine pancreas compensates for peripheral insulin resistance by higher insulin secretion.

Peripheral FA concentrations were positively associated with $\mathrm{P}_{\text {ins }}$ and the area and number of pancreatic islets. Fatty acids seem to have a dual effect on the insulin secretory capacity of the pancreas. Initially, slightly elevated FA concentrations seem to stimulate the insulin secretory capacity of the endocrine pancreas in pregnant dairy cows at the end of the dry period, as demonstrated in the present study. Prolonged exposure

Table 5. Insulin sensitivity parameters (means \pm SEM) determined during intravenous glucose tolerance tests (IVGTT) in optimal-conditioned $(2.5<\mathrm{BCS} \leq 3.5 ; \mathrm{n}=5)$ and overconditioned $(3.5<\mathrm{BCS} \leq 5 ; \mathrm{n}=5)$ dairy cows at the end of pregnancy (adapted from De Koster et al., 2016)

\begin{tabular}{|c|c|c|c|}
\hline Variable & Optimal conditioned & Overconditioned & $\mathrm{P}$-value \\
\hline Basal glucose (mg/dL) & $63.8 \pm 1.54$ & $69.0 \pm 2.87$ & 0.15 \\
\hline $\mathrm{P}_{\mathrm{glu}}^{1}(\mathrm{mg} / \mathrm{dL})$ & $188.2 \pm 6.5$ & $214.0 \pm 6.94$ & $<0.05$ \\
\hline $\mathrm{Si}^{2}\left(\times 10^{-4}\right.$ per $\mu \mathrm{IU} / \mathrm{mL}$ per min $)$ & $1.29 \pm 0.42$ & $0.77 \pm 0.16$ & 0.28 \\
\hline $\mathrm{AUC}_{\mathrm{glu}, 0-60}{ }^{3}$ & $5,761 \pm 201$ & $6,737 \pm 455$ & 0.09 \\
\hline $\mathrm{AUC}_{\mathrm{glu}, 0-120_{0}}$ & $7,648 \pm 444$ & $9,071 \pm 818$ & 0.17 \\
\hline $\mathrm{AUC}_{\mathrm{glu}, 0-180}{ }^{3}$ & $8,076 \pm 515$ & $9,563 \pm 972$ & 0.21 \\
\hline
\end{tabular}


to high FA concentrations, however, has been associated with decreased functioning of the endocrine pancreas in cows during early lactation, as described by Vanholder et al. (2005) and Bossaert et al. (2010). Studies in humans (Jensen, 2006; Kahn et al., 2006) and dairy cows (Bossaert et al., 2008) showed that chronic exposure to elevated FA levels is associated with lowered peripheral insulin concentrations. The latter has been referred to as the "lipotoxic effect," which leads to $\beta$-cell dysfunction and an accompanied impairment of the secretory capacity of the endocrine pancreas (Steiner et al., 2010). We therefore speculate that any lipotoxic effect of FA on pancreatic endocrine function in dairy cows might be more attributable to prolonged exposure to high FA concentrations, although more research is needed to confirm this conclusion. The underlying pathogenesis of this lipotoxic effect has been attributed to excessive endoplasmatic reticulum stress, the formation of reactive long-chain fatty acyl-CoA, activation of protein kinase $\mathrm{C}-\delta$, and an increase in oxidative stress (Hutley and Prins, 2005; Jensen, 2006; Cnop, 2008), leading to apoptosis of $\beta$-cells.

\section{CONCLUSION}

Our results demonstrated that overconditioning in pregnant dairy cows at the end of the dry period is associated with changes in pancreatic histology and the functioning of pancreatic $\beta$-cells. Overconditioned cows had more fat in their pancreas and an increase in the area of the endocrine pancreas, which was caused by an increase in the area, but not number, of islets. The insulin secretory capacity of the pancreas in overconditioned cows was increased, which compensated for the peripheral insulin resistance.

\section{ACKNOWLEDGMENTS}

This research was funded by the Special Research Fund of Ghent University (grant number 01D28410). The authors cordially thank Lobke De Bels (Department of Morphology, Faculty of Veterinary Medicine, Ghent University, Belgium) for excellent technical assistance.

\section{REFERENCES}

Bell, A. W., and D. E. Bauman. 1997. Adaptations of glucose metabolism during pregnancy and lactation. J. Mammary Gland Biol. Neoplasia 2:265-278.

Bossaert, P., H. De Cock, J. L. Leroy, S. De Campeneere, P. E. Bols, M. Filliers, and G. Opsomer. 2010. Immunohistochemical visualization of insulin receptors in formalin-fixed bovine ovaries post mortem and in granulosa cells collected in vivo. Theriogenology $73: 1210-1219$
Bossaert, P., J. L. Leroy, S. De Vliegher, and G. Opsomer. 2008. Interrelations between glucose-induced insulin response, metabolic indicators, and time of first ovulation in high-yielding dairy cows. J. Dairy Sci. 91:3363-3371.

Boston, R. C., D. Stefanovski, P. J. Moate, A. E. Sumner, R. M. Watanabe, and R. N. Bergman. 2003. MINMOD Millennium: A computer program to calculate glucose effectiveness and insulin sensitivity from the frequently sampled intravenous glucose tolerance test. Diabetes Technol. Ther. 5:1003-1015.

Cardoso, F. C., W. Sears, S. LeBlanc, and J. Drackley. 2011. Technical note: Comparison of 3 methods for analyzing areas under the curve for glucose and nonesterified fatty acids concentrations following epinephrine challenge in dairy cows. J. Dairy Sci. 94:6111-6115.

Cerf, M. E. 2013. Beta cell dysfunction and insulin resistance. Front. Endocrinol. 4:37.

Cnop, M. 2008. Fatty acids and glucolipotoxicity in the pathogenesis of type 2 diabetes. Biochem. Soc. Trans. 36:348-352.

Cnop, M., J. Vidal, R. L. Hull, K. M. Utzschneider, D. B. Carr, T. Schraw, P. E. Scherer, E. J. Boyko, W. Y. Fujimoto, and S. E. Kahn. 2007. Progressive loss of beta-cell function leads to worsening glucose tolerance in first-degree relatives of subjects with type 2 diabetes. Diabetes Care 30:677-682.

De Koster, J., M. Hostens, K. Hermans, W. Van Den Broeck, and G. Opsomer. 2016. Validation of different measures of insulin sensitivity of glucose metabolism in dairy cows using the hyperinsulinemic euglycemic clamp test as the gold standard. Domest. Anim. Endocrinol. 57:117-126.

De Koster, J., M. Hostens, M. Van Eetvelde, K. Hermans, S. Moerman, H. Bogaert, E. Depreester, W. Van Den Broeck, and G. Opsomer. 2015. Insulin response of the glucose and fatty acid metabolism in dry dairy cows across a range of body condition scores. J. Dairy Sci. 98:4580-4592.

De Koster, J. D., and G. Opsomer. 2013. Insulin resistance in dairy cows. Vet. Clin. North Am. Food Anim. Pract. 29:299-322.

DeFronzo, R. A. 2004. Pathogenesis of type 2 diabetes mellitus. Med. Clin. North Am. 88:787-835.

Edmonson, A., I. Lean, L. Weaver, T. Farver, and G. Webster. 1989. A body condition scoring chart for Holstein dairy cows. J. Dairy Sci. 72:68-78.

Hayirli, A. 2006. The role of exogenous insulin in the complex of hepatic lipidosis and ketosis associated with insulin resistance phenomenon in postpartum dairy cattle. Vet. Res. Commun. 30:749-774.

Holtenius, K., S. Agenäs, C. Delavaud, and Y. Chilliard. 2003. Effects of feeding intensity during the dry period. 2. Metabolic and hormonal responses. J. Dairy Sci. 86:883-891.

Howard, V., and M. Reed. 2004. Chapter 2.7: A systematic random sample in 2D and 3D. Page 26 in Unbiased Stereology: ThreeDimensional Measurement in Microscopy. Garland Science, New York, NY.

Hutley, L., and J. B. Prins. 2005. Fat as an endocrine organ: Relationship to the metabolic syndrome. Am. J. Med. Sci. 330:280-289.

Jaakson, H., P. Karis, K. Ling, A. Ilves-Luht, J. Samarütel, M. Henno, I. Jõudu, A. Waldmann, E. Reimann, P. Pärn, R. M. Bruckmaier, J. J. Gross, T. Kaart, M. Kass, and M. Ots. 2018. Adipose tissue insulin receptor and glucose transporter 4 expression, and blood glucose and insulin responses during glucose tolerance tests in transition Holstein cows with different body condition. J. Dairy Sci. 101:752-766.

Jensen, M. D. 2006. Adipose tissue as an endocrine organ: Implications of its distribution on free fatty acid metabolism. Eur. Heart J. Suppl. 8:13-19.

Kahn, C. R. 1978. Insulin resistance, insulin insensitivity, and insulin unresponsiveness: A necessary distinction. Metabolism 27:18931902.

Kahn, S. E. 2003. The relative contributions of insulin resistance and beta-cell dysfunction to the pathophysiology of type 2 diabetes. Diabetologia 46:3-19.

Kahn, S. E., R. L. Hull, and K. M. Utzschneider. 2006. Mechanisms linking obesity to insulin resistance and type 2 diabetes. Nature 444:840-846. 
Kerestes, M., V. Faigl, M. Kulcsár, O. Balogh, J. Földi, H. Fébel, Y. Chilliard, and G. Huszenicza. 2009. Periparturient insulin secretion and whole-body insulin responsiveness in dairy cows showing various forms of ketone pattern with or without puerperal metritis. Domest. Anim. Endocrinol. 37:250-261.

Morrow, D. A. 1976. Fat cow syndrome. J. Dairy Sci. 59:1625-1629.

NRC. 2001. Nutrient Requirements of Dairy Cattle. Vol. 1. 7th ed. National Academies Press, Washington, DC.

Opsomer, G., T. Wensing, H. Laevens, M. Coryn, and A. de Kruif. 1999. Insulin resistance: The link between metabolic disorders and cystic ovarian disease in high yielding dairy cows? Anim. Reprod. Sci. 56:211-222.

Pacini, G., and R. N. Bergman. 1986. MINMOD: A computer program to calculate insulin sensitivity and pancreatic responsivity from the frequently sampled intravenous glucose tolerance test. Comput. Methods Programs Biomed. 23:113-122.

Pires, J. A., A. H. Souza, and R. R. Grummer. 2007. Induction of hyperlipidemia by intravenous infusion of tallow emulsion causes insulin resistance in Holstein cows. J. Dairy Sci. 90:2735-2744.

Reynolds, C. K., P. C. Aikman, B. Lupoli, D. J. Humphries, and D. E. Beever. 2003. Splanchnic metabolism of dairy cows during the transition from late gestation through early lactation. J. Dairy Sci. 86:1201-1217.

Roche, J. R., J. K. Kay, N. C. Friggens, J. J. Loor, and D. P. Berry. 2013. Assessing and managing body condition score for the preven- tion of metabolic disease in dairy cows. Vet. Clin. North Am. Food Anim. Pract. 29:323-336.

Rorsman, P., and M. Braun. 2013. Regulation of insulin secretion in human pancreatic islets. Annu. Rev. Physiol. 75:155-179.

Saltiel, A. R., and C. R. Kahn. 2001. Insulin signalling and the regulation of glucose and lipid metabolism. Nature 414:799-806.

Schoenberg, K. M., R. M. Ehrhardt, and T. R. Overton. 2012. Effects of plane of nutrition and feed deprivation on insulin responses in dairy cattle during late gestation. J. Dairy Sci. 95:670-682.

Schröder, U. J., and R. Staufenbiel. 2006. Invited review: Methods to determine body fat reserves in the dairy cow with special regard to ultrasonographic measurement of backfat thickness. J. Dairy Sci. 89:1-14.

Steiner, D. J., A. Kim, K. Miller, and M. Hara. 2010. Pancreatic islet plasticity: interspecies comparison of islet architecture and composition. Islets 2:135-145.

Vanholder, T., J. L. Leroy, J. Dewulf, L. Duchateau, M. Coryn, A. de Kruif, and G. Opsomer. 2005. Hormonal and metabolic profiles of high-yielding dairy cows prior to ovarian cyst formation or first ovulation post partum. Reprod. Domest. Anim. 40:460-467.

Weyer, C., C. Bogardus, D. M. Mott, and R. E. Pratley. 1999. The natural history of insulin secretory dysfunction and insulin resistance in the pathogenesis of type 2 diabetes mellitus. J. Clin. Invest. 104:787-794. 